\title{
O papel dos intelectuais e a literatura de resistência política na revista Literatura Chilena en el Exilio
}

\section{The role of intellectuals and the literature of political resistance in the journal Literatura Chilena en el Exilio}

\author{
Raphael Coelho Neto ${ }^{1}$
}

\begin{abstract}
Resumo Literatura Chilena en el Exilio (1977-1980) foi uma revista cultural, de forte caráter político, fundada e dirigida no exílio em Los Angeles, EUA, no contexto da ditadura militar no Chile, pelos escritores e críticos literários Fernando Alegría e David Valjalo. Essa publicação trimestral divulgou, amplamente, em suas páginas, textos de resistência política que, por vezes, difundiram ideias, discursos e valores vinculados às esquerdas no Chile. Por conseguinte, abriu-se espaço considerável na revista para a reflexão acerca do papel do escritor/intelectual durante as ditaduras do Cone Sul. Assim, o objetivo deste artigo consiste em analisar as relações entre a literatura de resistência política, com ênfase na crítica a respeito dos testimonios, e a função dos intelectuais em Literatura Chilena en el Exilio. Tendo esse impresso como fonte e objeto de estudo, estabelecemos como central em nossa proposta refletir de que maneira os textos veiculados - ensaios, discursos e crítica literária - dialogaram com o editorialismo programático da revista.
\end{abstract}

Palavras-Chave Literatura Chilena en el Exilio; literatura de resistência política; papel dos intelectuais.

Abstract Literatura Chilena en el Exilio (1977-1980) was a cultural journal, with a strong political stance, founded and directed, in exile, by the literary writers and critics Fernando Alegría and David Valjalo, from Los Angeles, EUA, under the context of the military dictatorship in Chile. This quarterly publication divulged, broadly, in its pages, political resistance texts which, at times, spread ideas, discourses and values linked to the Left in Chile. Therefore, there was a considerable space in the journal for a reflection about the role of writer/intellectual during the Southern Cone dictatorships period. The objective of this article is to analyze the relationship between the political resistance literature, with an emphasis on the criticism of the testimonios, and the role of

\footnotetext{
${ }^{1}$ Mestrando em História e Culturas Políticas pelo Programa de Pós-Graduação em História da Faculdade de Filosofia e Ciências Humanas da Universidade Federal de Minas Gerais (UFMG). Título da pesquisa: Exílio, Intelectuais e Literatura de Resistência Política nas revistas Literatura Chilena en el Exilio/Literatura Chilena, Creación y Crítica e Araucaria de Chile. Órgão financiador: Coordenação de Aperfeiçoamento de Pessoal de Nível Superior (CAPES). E-mail: raphaelcneto@ yahoo.com.br.
}

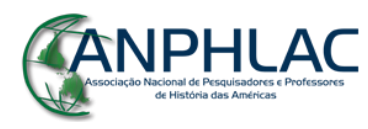

Revista Eletrônica da ANPHLAC, ISSN 1679-1061, №. 19, p. 152-185, jul./dez., 2015. http://revista.anphlac.org.br 
intellectuals in the Literatura Chilena en el Exilio. Having this printed journal as a source and object of study, we set as the central point of our proposal a reflection on how the texts that were published - essays, speeches and literary criticism - were connected to the editorialismo programático of the journal.

Keywords Literatura Chilena en el Exilio; politics of resistance literature; role of Intellectuals.

Artigo recebido em: 23/08/2015

Artigo aprovado para publicação em: 03/12/2015

\section{Introdução}

Literatura Chilena en el Exilio/Literatura Chilena, Creación y Crítica foi uma revista cultural e política. De circulação trimestral, foi publicada no exílio em Los Angeles, nos Estados Unidos, pela editora Ediciones de la Frontera, no contexto da ditadura militar no Chile (1973-1990). Seu primeiro número foi lançado em janeiro de 1977. A revista, inicialmente chamada Literatura Chilena en el Exilio, foi fundada e dirigida pelo escritor e crítico literário chileno Fernando Alegría (1918-2005), ${ }^{2}$ e contava também com o poeta chileno, David Valjalo (1924-2005), ${ }^{3}$ como seu cofundador e editor. Os escritores, professores e críticos literários chilenos Jaime Concha e Juan Armando Epple compuseram seu Conselho Editorial. Ambos estiveram exilados nos Estados

\footnotetext{
${ }^{2}$ Fernando Alegría (1918-2005) nasceu em Santiago de Chile, no dia 26 de setembro de 1918. Foi novelista, poeta, ensaísta e professor universitário. Titulou-se como professor de castelhano e filosofia no Instituto Pedagógico da Universidade de Chile, e se doutorou pela Universidade da Califórnia. Pertenceu à Geração Literária de 1938, movimento que se notabilizou pela abordagem temática sobre os problemas sociais e políticos nas obras dos escritores que o compuseram, muitos deles marxistas. Alegría, não obstante tenha recebido reconhecimento nacional por suas novelas e suas poesias, teve sua narrativa marcada pelos estudos biográficos de dois personagens da esquerda chilena: Luis Emilio Recabarren e Salvador Allende. Com o presidente socialista chileno, de quem foi amigo, trabalhou no governo da Unidade Popular (UP) como agregado cultural na embaixada do Chile em Washington, Estados Unidos, até o golpe de 1973. Permaneceu nos EUA durante a ditadura de Augusto Pinochet. Informações disponíveis em: http://www.memoriachilena.cl. Acesso em: 25/06/2013.

${ }^{3}$ David Valjalo (1924-2005), também responsável pela direção da revista Literatura Chilena en el Exilio, nasceu em Iquique, no Chile, em 1924. Foi poeta, narrador e ensaísta, adquirindo maior destaque na poesia e na crítica literária através de obras como Poemas de la resistência (1985), sua visão poética sobre o exílio, e Antologia de poesia chilena, a través del soneto (1988). Nos Estados Unidos desde 1959, contribuiu para a difusão da arte latino-americana apresentando o teatro e a lírica através de seu "Teatro de Cámara". Criou e manteve a editora Ediciones de la Frontera, voltada para a publicação da literatura chilena no exílio e da revista Literatura Chilena en el Exilio/Literatura Chilena, Creación y Crítica. Como Fernando Alegría, ele também trabalhou no governo de Salvador Allende, exercendo a função de Adido Cultural da UP, na Califórnia, onde se manteve após o golpe militar de 1973. Ver VALJALO (1990, p. 137-138); WYMAN (2002, p. 463).
}

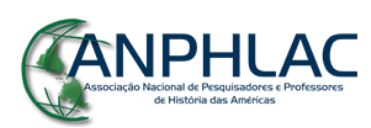

Revista Eletrônica da ANPHLAC, ISSN 1679-1061, №. 19, p. 152-185, jul./dez., 2015. http://revista.anphlac.org.br 
Unidos durante a ditadura de Augusto Pinochet, país no qual construíram importante trajetória acadêmica como professores universitários e críticos. Exilado na Holanda, onde foi professor na Universidade de Amsterdã, o crítico Guillermo Araya também integrou o Conselho de Literatura Chilena.

A história da revista pode ser dividida em dois momentos: o primeiro vai de janeiro de 1977 a abril de 1980, quando, até o $14^{\circ}$ número, era denominada Literatura Chilena en el Exilio; o segundo iniciou-se no primeiro trimestre de 1981, quando o impresso passou a se chamar Literatura Chilena, Creación y Crítica, seguindo sua publicação até 1994. Com o fim da ditadura chilena em 1990, as edições de Literatura Chilena, Creación y Crítica, do $\mathrm{n}^{\circ} 51$ ao 58, foram publicadas em Santiago de Chile. No entanto, interessa-nos analisar suas edições de 1977 até 1980, período em que a revista manteve-se no exílio sob a direção de Fernando Alegría, ainda com a denominação de Literatura Chilena en el Exilio. Embora Literatura Chilena, Creación y Crítica, em nossa pesquisa de mestrado, seja também objeto de estudo, optamos por não contemplá-la neste trabalho por não termos ainda uma investigação mais consistente a respeito dessa segunda fase da revista, quando David Valjalo assumiu a dupla função de diretor e editor, sem a presença de Fernando Alegría. Pelos dados levantados até o momento, acreditamos que Literatura Chilena, Creación y Crítica tenha passado por algumas transformações em sua linha editorial, ainda militante e pautada pela resistência política à ditadura, porém menos vinculada aos valores das esquerdas no Chile.

Literatura Chilena en el Exilio apresentava um formato simples, impressa em preto e branco em papel-jornal, contendo em média 36 páginas por edição. Somente sua capa e seu sumário apresentavam-se coloridos, porém sem maiores trabalhos gráficos, figurando, na primeira, apenas o nome da revista e a edição a qual pertencia. ${ }^{4}$ Em Carta do Editor do Indice General da segunda fase da revista, como Literatura Chilena, Creación y Crítica, David Valjalo (1984, p. 3), referindo-se à trajetória do impresso até aquele momento, explicou que sua única fonte de recursos econômicos foi a colaboração de seus assinantes, insistindo que Literatura Chilena en el Exilio/Literatura Chilena,

\footnotetext{
${ }^{4}$ A nossa descrição feita a respeito da materialidade da revista foi pautada em suas edições digitais, disponíveis no site da Biblioteca Nacional de Chile, www.memoriachilena.cl. Não tivemos acesso físico à revista até o momento.
}

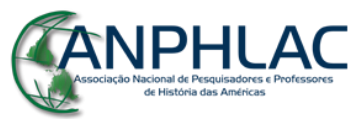

Revista Eletrônica da ANPHLAC, ISSN 1679-1061, №. 19, p. 152-185, jul./dez., 2015. http://revista.anphlac.org.br 
Creación y Crítica não recebia nenhuma contribuição financeira de partido político, instituição cultural ou fundação.

Por sua materialidade simples e pela pouca quantidade de página por edição, é possível inferir que a revista, de fato, não tenha tido maiores fontes de recursos. Isso nos faz pensar, embora não tenhamos, precisamente, esta informação, que a tiragem de Literatura Chilena en el Exilio não deva ter sido muito elevada, circulando, possivelmente, entre a comunidade intelectual e acadêmica chilena do exílio nos Estados Unidos, no Canadá, no México e em parte da Europa. Além de Fernando Alegría, David Valjalo, Juan Armando Epple e Jaime Concha, membros do Conselho Editorial que viviam exilados nos Estados Unidos, importantes escritores que frequentemente colaboraram com a revista estiveram exilados, majoritariamente, nesse país ou no Canadá. Literatura Chilena en el Exilio, inclusive, destinou sua seção Poesia, voltada para a produção poética de exílio, em duas oportunidades, somente para escritores chilenos exilados nos dois países. ${ }^{5}$ Isso evidencia uma importante rede intelectual ${ }^{6}$ de críticos, escritores e acadêmicos que se consolidou no exílio, sobretudo na América do Norte, em torno da revista. Rubí Carreño explica que o exílio de intelectuais chilenos nos Estados Unidos, em especial aqueles ligados à literatura e à crítica literária, e os contatos estabelecidos entre eles durante o desterro foram possibilitados por três fatores centrais:

\begin{abstract}
A las redes de intelectuales chilenos que ya se encontraban trabajando en ese país [como foi o caso de David Valjalo]; a que muchos de los críticos poseían el grado de doctor otorgado por universidades de primer nivel y a la solidaridad de los académicos y jefes de departamento norteamericanos (CARREÑO, 2009, p. 132).
\end{abstract}

\footnotetext{
${ }^{5}$ Em Literatura Chilena en el Exilio, n. 7, colaboraram os seguintes poetas chilenos exilados no Canadá: Gonzalo Millán, Jorge Etcheverry, Francisco Viñuela, Manuel Jofré, Javier Campos, Manuel Aránguiz, Jorge Cancino, Nelly Herrero e Naín Nómez. Em Literatura Chilena en el Exilio, n. 13, foram publicados poemas de escritores chilenos nos Estados Unidos: Oscar Hahn, Raul Barrientos, Jaime Giordano, Luis Dominguez, Pedro Lastra, Lucia Waizer Fuenzalida, Jaime Valdivieso, além dos próprios Juan Armando Epple, David Valjalo e Fernando Alegría. Estes três últimos, junto a Naín Nómez, no Canadá, publicaram frequentemente na revista como críticos literários. No que tange aos críticos literário, musical e teatral chilenos exilados nos Estados Unidos, destacamos os frequentes colaboradores Bernardo Subercaseaux, Pedro Bravo-Elizondo e Marcelo Coddou.

${ }^{6}$ Entendemos por rede intelectual " [...] una forma de sociabilidad y una cadena de contactos e interacción entre artistas, gente de letras, editores y otros tipos de agentes culturales, ligados por convicciones ideológicas o estéticas compartidas [...]" (ALTAMIRANO, 2010, p. 18-19), embora essa condição não elimine a possibilidade de haver pensamentos plurais e, por vezes, divergências dentro dos grupos. Ver também: DEVÉS-VALDÉS (2007).
}

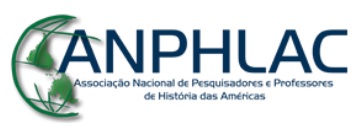

Revista Eletrônica da ANPHLAC, ISSN 1679-1061, №. 19, p. 152-185, jul./dez., 2015. http://revista.anphlac.org.br 
Concedendo espaço a escritores e críticos chilenos e ajudando a consolidar, no exílio, essa rede de sociabilidade intelectual, Literatura Chilena en el Exilio foi receptiva à grande parte da produção literária chilena do pós-golpe, a do exílio e àquela que chegava clandestinamente do Chile para sua redação em Los Angeles. Embora não a definamos como uma revista estritamente literária, a literatura certamente mereceu destaque significativo em suas páginas, sobretudo a de caráter político. Na mesma proporção dos poemas, dos contos e das novelas que surgiram, de maneira significativa, como forma de combate à ditadura no Chile, existiu uma importante corrente de escritores, ensaístas e críticos literários que buscaram, concomitantemente, analisar essa literatura política. Literatura Chilena en el Exilio deu vazão a muitas dessas análises. Dentro dos debates que se consumaram a respeito, o papel político do intelectual também se apresentou na revista como um dos assuntos mais candentes.

Assim, como objetivo central deste artigo, propomos uma discussão baseada na análise dos debates estabelecidos pelos colaboradores de Literatura Chilena en el Exilio acerca da função do escritor/intelectual, sua relevância política enquanto resistência e oposição aos governos ditatoriais da América Latina, bem como as reflexões suscitadas pela crítica literária chilena concernentes à literatura de resistência política, com ênfase na de caráter testemunhal. Buscamos, com isso, perceber a veiculação de ideias dentro de uma rede de relações intelectuais estabelecida por uma revista cultural e política, profundamente marcada pela condição do exílio. Nosso intuito é preencher um vazio na historiografia, sobretudo a brasileira, a respeito desse impresso, cuja trajetória na luta contra o regime autoritário no Chile não foi devidamente contemplada até o momento. Com maior frequência, a revista foi estudada como fonte para a análise da produção cultural chilena no exílio, ${ }^{7}$ e não como objeto, como propomos. Dessa forma, importa-

\footnotetext{
${ }^{7}$ Nesse aspecto, citamos os trabalhos de Paloma Vidal (2004), Naín Nómez (2007) e Carmen Norambuena (2008). Os três autores utilizam Literatura Chilena en el Exilio como fonte e mencionam a importância da revista na resistência cultural e política à ditadura no exílio. Todavia, não foi preocupação de seus estudos compreender a revista enquanto um projeto coletivo, sua trajetória político-cultural no exílio, o que a transformaria em objeto de análise. O estudo que mais se aproxima da nossa proposta é o já citado texto de Rubí Carreño (2009). Embora o objetivo central de seu artigo tenha sido analisar o desterro da crítica literária chilena durante a ditadura militar de Augusto Pinochet, a autora retrata Literatura Chilena en el Exilio como uma das principais iniciativas intelectuais no exílio, ao lado de outra importante revista,
}

\section{GANPHLAC}

Revista Eletrônica da ANPHLAC, ISSN 1679-1061, N. 19, p. 152-185, jul./dez., 2015. http://revista.anphlac.org.br 
nos compreender de que maneira os debates suscitados em Literatura Chilena en el Exilio a respeito da função social e política da literatura e dos intelectuais dialogaram com seu editorialismo programático.

Por editorialismo programático, com base na proposta teórica e metodológica de Fernanda Beigel (2003, p. 108), compreendemos a perspectiva editorial política e militante de determinado periódico, alinhada a sua vertente cultural. Essa ideia, embora brevemente desenvolvida por Beigel, é extremamente importante para nós na medida em que pressupõe a articulação entre política e literatura. Dessa maneira, torna-se importante pensarmos de que modo tal articulação poderia materializar-se, por meio de Literatura Chilena en el Exilio, em novas formas de difusão cultural atreladas a aspirações políticas, por vezes revolucionárias. Reiteramos que a ideia de editorialismo programático permitirnos-á entrelaçar o projeto coletivo de Literatura Chilena en el Exilio, marcadamente político, por ser um polo de resistência à ditadura no exílio, com a literatura e a crítica literária publicadas em suas páginas, bem como com as perspectivas sobre o papel do intelectual desenvolvidas por seus colaboradores.

Torna-se relevante pensar que as revistas culturais constituem-se em instrumentos imprescindíveis para o estudo dos movimentos ocorridos no âmbito literário de determinado país ou região, em dado momento histórico. Elas oferecem-nos, com maior abrangência e dinâmica, as inovações estéticas, temáticas e ideológicas de escritores ou de movimentos literários, em seu sentido mais lato. Nesses impressos, são debatidos os temas da atualidade, fornecendo-nos uma visão ampla da dinâmica de atração e rechaço entre os grupos literários. Pensamos que as revistas de cultura e política, como Literatura Chilena en el Exilio, são instrumentos ideais para o estudo dos debates da crítica literária, como defende Roxana Patiño (2009, p. 461-462), ao apontar que cada época constrói um desenho particular das relações da crítica com os outros discursos e com os espaços de circulação desses discursos.

Araucaria de Chile, nas quais se reuniu parte significativa da crítica chilena exilada. Ao evocar importantes críticos literários que contribuíram com Literatura Chilena..., Carreño, ainda que sumariamente, correlaciona as proposições estético-políticas da crítica à atuação da revista enquanto bem cultural de resistência política no exílio.

\section{GANPHLAC}

Revista Eletrônica da ANPHLAC, ISSN 1679-1061, №. 19, p. 152-185, jul./dez., 2015. http://revista.anphlac.org.br 
Enquanto projetos coletivos, torna-se importante perceber que as revistas, de maneira geral, proporcionam o compartilhamento de ideias, discursos, personagens e visões de mundo que, no caso de Literatura Chilena en el Exilio, estiveram voltados para valores democráticos a partir dos campos socialista e comunista, em especial. A questão da resistência e da oposição política, portanto, em Literatura Chilena, vinculou-se, em grande medida, a visões de mundo, ideais e personagens historicamente ligados às esquerdas chilenas.

Passemos, então, para as análises acerca do papel do intelectual e da função social da literatura na revista de exílio objeto de nosso estudo.

\section{A função pública dos intelectuais: entre a criação artístico-literária e o engajamento político}

Logo em seu primeiro número, o editorial de abertura de Literatura Chilena evidenciou a preocupação da revista com a fragmentação do campo cultural no Chile. Seus editores enfatizaram a necessidade de atuação conjunta dos chilenos, especialmente dos intelectuais exilados, no combate ao que denominaram de "ditadura gorila", opondose ferrenhamente aos ataques de todas as ordens do "obscurantismo reacionário" (EDITORIAL, 1977, p. 1).

Novamente, essa ideia fez-se presente no editorial da segunda edição da revista. Nele, Fernando Alegría e David Valjalo explicitaram quais deveriam ser os objetivos precípuos dos escritores chilenos no exílio: o combate à ditadura e a luta pela democracia. Nessa perspectiva, as vertentes ideológicas e partidário-políticas entre a intelectualidade chilena exilada deveriam ser colocadas em segundo plano, em nome da unidade política dos escritores pelos direitos humanos e pelas liberdades democráticas:

\footnotetext{
A esa unidad, en vías de hacerse firme y perdurable, dedicamos nuestra empresa de escritores en el exilio: la patria requiere el ímpetu máximo de lucha y la voluntad ferviente de sacrificar los intereses individuales para reforzar el gran frente democrático antifascista. Con el pueblo de Chile, con su clase trabajadora y campesina, con sus profesionales y estudiantes, con todos los hombres y mujeres que se juegan enteros por la reconquista de la democracia,
}

\section{GANPHLAC}

Revista Eletrônica da ANPHLAC, ISSN 1679-1061, №. 19, p. 152-185, jul./dez., 2015. http://revista.anphlac.org.br 
van los escritores, artistas e intelectuales en el puesto de alta responsabilidad que les corresponde (EDITORIAL, 1977, p. 1).

Contudo, entendemos que a posição político-editorial militante da revista (editorialismo programático), ao reivindicar a unidade política em torno à democracia como ponto premente de união entre os intelectuais chilenos opositores a Pinochet, assim o fez atrelando-a a personagens e ideais socialistas e comunistas do Chile. Percebemo-lo, sobretudo, quando a revista pôs em relevo figuras como Salvador Allende e seu governo à frente da Unidade Popular (UP), bem como ao carregar, nos editoriais e nos textos admitidos, um anti-imperialismo em relação aos Estados Unidos, mesmo sendo publicada neste país. Isso demonstra que, para além da unidade política contra o regime pinochetista, a revista tinha, sim, outros objetivos precípuos que foram veiculados visando a unidade e a formação de frentes de resistência política a partir das esquerdas, em franca associação ao governo da UP. Assim, interpretamos que os editores de Literatura Chilena, ao proporem a atuação conjunta dos intelectuais exilados a favor da "reconquista de la democracia", vislumbram-na de modo a resgatar um legado democrático no Chile que viveu seu ponto triunfal, na perspectiva da esquerda que defendia o caminho institucional para o socialismo, durante o governo de Allende.

A edição de número 4 de Literatura Chilena deixou evidente a vinculação política da revista, enquanto projeto coletivo, com uma linha de continuidade em relação à "via chilena para o socialismo" de Salvador Allende. ${ }^{8}$ Podemos pensar, ao menos, que a revista mostrou-se atrelada às perspectivas de transformações políticas, sociais e culturais suscitadas pelo governo da UP em sua vertente mais allendista. No lugar do seu habitual editorial de apresentação de cada número, os editores de Literatura Chilena deram lugar a uma série de discursos, poemas, artigos e fragmentos de memórias de

\footnotetext{
${ }^{8}$ De uma maneira mais geral e sumária, com base nos estudos de Alberto Aggio (2002) e Marcelo Casals Araya (2010), a "via chilena para o socialismo" consistiu no projeto (o que envolveu tentativas de formulações teóricas e de exercício prático) de construção do socialismo no Chile através da utilização dos aparatos institucionais e democráticos do país, ou seja, dentro de uma legalidade democrática chilena, sem rupturas drásticas com o quadro político-institucional vigente, embora se buscasse alterá-lo. Tais condições lhe conferiram um caráter de originalidade se comparada a perspectivas revolucionárias mais ortodoxas que visavam a implantação do socialismo. Pressupunha-se, por exemplo, politicamente, a manutenção do pluralismo de partidos, inclusive no governo. Do ponto de vista social, o sentido de democracia presente nas propostas de transformação da UP pautava-se pela ampliação da participação popular nas questões políticas, culturais e econômicas.
}

\section{GANPHLAC}

Revista Eletrônica da ANPHLAC, ISSN 1679-1061, №. 19, p. 152-185, jul./dez., 2015. http://revista.anphlac.org.br 
personagens significativos ligados ao governo da UP e a Allende. A sequência de textos, publicados postumamente e interpretados pela revista como testemunhais, foi intitulada "Los héroes de septiembre tienen la palabra". Nela, foram contemplados: o discurso de Salvador Allende, proferido momentos antes de sua morte; o último poema de Víctor Jara, escrito na prisão dias antes de ser brutalmente assassinado pelos agentes das forças de repressão da Junta Militar; parte das memórias de Pablo Neruda, escritas três dias após a morte de Salvador Allende e nove antes de seu falecimento, transformadas no livro póstumo Confieso que he vivido (1974); o fragmento do livro Una vida por la legalidad, memórias do Comandante em Chefe do Exército chileno durante o governo da UP, Carlos Prats, redigidas em 1974 - mesmo ano do atentado a bomba que o matou -, nas quais se evidencia a trajetória legalista e de fidelidade do general em relação a Salvador Allende; o último artigo de Orlando Letelier, embaixador chileno no governo da UP em Washington, nos Estados Unidos, publicado no jornal The New York Times em setembro de 1976, dias após seu assassinato por um agente da CIA a mando do serviço de inteligência da ditadura chilena, a DINA; e, por fim, um discurso do socialista José Tohá, Ministro do Interior e de Defesa do governo de Salvador Allende, assassinado em 15 de março de 1974 em um Hospital Militar, para onde foi levado após sofrer uma série de torturas no "campo de concentração" de Isla Dawson. ${ }^{9}$

Como foi possível perceber, em comum a todos os "heróis de setembro", falecidos neste mês, à exceção de José Tohá, esteve o fato de terem sido mortos, direta ou indiretamente, em razão do golpe e/ou da atuação das forças de repressão da ditadura chilena. Literatura Chilena buscou ressaltar nesses personagens a condição de "mártires" em função da resistência e do comprometimento até a morte com a causa socialista no Chile através do projeto da via chilena da UP. Podemos dizer, ainda, que, ao retomar tais personagens históricos, a revista, de maneira latente, representou-os como paradigmas de um tipo de engajamento político que ela defendia para os intelectuais no exílio. ${ }^{10}$

\footnotetext{
${ }^{9}$ Ver Los héroes de septiembre tienen la palabra. Literatura Chilena en el Exilio, Los Angeles, n. 4, 1977 , p. 1-8.

${ }^{10}$ Nesse sentido, analisaremos, nas páginas seguintes deste artigo, as representações de Salvador Allende pelos colaboradores de Literatura Chilena en el Exilio, incluindo a reprodução de parte do seu último discurso supracitado. Assim o faremos também em relação ao poeta Pablo Neruda e ao músico, professor e ativista político Víctor Jara, ainda que de maneira mais sumária.
}

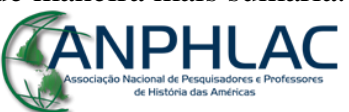

Revista Eletrônica da ANPHLAC, ISSN 1679-1061, №. 19, p. 152-185, jul./dez., 2015. http://revista.anphlac.org.br 
Acerca do papel dos intelectuais, da literatura e das artes, Fernando Alegría, em seu discurso inaugural das Jornadas Culturales Salvador Allende - realizadas no México, em setembro de 1978 -, ${ }^{11}$ publicado no oitavo número de Literatura Chilena en el Exilio, sentenciou que

\begin{abstract}
Nunca la literatura y el arte de Chile, fuera y dentro del país, en el exilio tanto como en la resistencia, han dado tan clara muestra como hoy de haber llegado al umbral de un poderoso y fecundo renacimiento. Nuestros pintores y escultores, novelistas y poetas, dramaturgos, cineastas y músicos, golpean a diario las puertas de la dictadura para recordarles a los esbirros que estamos vivos, que la voz de Chile no se ahoga, que el pueblo numera los días de la espera con valerosas y potentes creaciones (ALEGRÍA, 1978, p. 24).
\end{abstract}

Percebemos que Fernando Alegría conferiu à noção de intelectual um sentido de compromisso político e ação no espaço público que, naquele momento, inscrever-se-ia, para além da resistência política às ditaduras, na defesa da democracia, das liberdades políticas e da justiça social, coerente com as ideias defendidas nos editoriais da revista. Escrever tornar-se-ia, dessa forma, um meio de ação, e nada mais premente para o escritor do que se ocupar do seu mundo, das questões que o envolviam.

Sob uma ótica de comprometimento do intelectual similar a de Fernando Alegría, Soledad Bianchi publicou sua crítica literária a respeito da política nas letras das canções de Víctor Jara. Bianchi procurou evidenciar como o importante compositor e militante comunista chileno, torturado e assassinado pelos militares dias após o golpe de 11 de setembro de 1973, como expressamos, acolheu em sua obra musical e poética uma concepção política de engajamento social, propondo reflexões sobre a função do poeta e

\footnotetext{
${ }^{11}$ As Jornadas Culturales Salvador Allende ocorreram no México, entre 4 e 10 de setembro de 1978, organizadas por Casa de Chile en México. Essa importante instituição foi fundada, representativamente, em 11 de setembro de 1974, um ano após o golpe, por iniciativa do socialista Pedro Vuskovic Bravo (exMinistro da Economia do governo de Salvador Allende), que atuou, de maneira a consolidar esse intento, junto ao governo do México e a intelectuais mexicanos. Através de Casa de Chile, parte significativa da resistência política chilena no exílio efetivou sua resistência à ditadura liderada por Pinochet. As Jornadas Culturales Salvador Allende, realizadas, também simbolicamente, em setembro de 1978, cinco anos após a queda do governo de Allende, contaram ainda com o patrocínio e a organização da revista Literatura Chilena en el Exilio - que divulgou sobremaneira a programação e os debates promovidos pelo evento, especialmente em seu oitavo número -, bem como do Instituto Nacional de Bellas Artes (INBA) e do Departamento de Difusión de la Universidad Autónoma de México (UNAM). Sobre Casa de Chile en México, ver: ROJAS MIRA (2013).
}

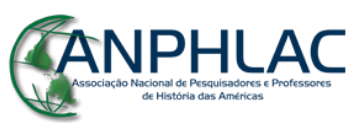

Revista Eletrônica da ANPHLAC, ISSN 1679-1061, №. 19, p. 152-185, jul./dez., 2015. http://revista.anphlac.org.br 
do artista. ${ }^{12}$ Soledad Bianchi explicitou qual foi seu objetivo ao analisar, em linhas gerais, a obra de Víctor Jara, deixando entrever também seu posicionamento favorável ao compositor:

\begin{abstract}
lo que me interesa es mostrar cómo Victor Jara acoge en su obra una concepción sobre la función del poeta; es decir, cómo se traduce su compromiso político en su quehacer poético. [Interesa] Explicitar la relación entre la labor política del artista, su actividad artística y su producción, y poder aproximarse - en una primera mirada - a su concepción de su quehacer como poeta y como cantante a través de su obra (BIANCHI, 1978, p. 5).
\end{abstract}

Fica evidente que arte e política, para os dois importantes críticos literários chilenos, Fernando Alegría e Soledad Bianchi, nesse contexto de ditaduras militares e imperialismo no Cone Sul, não se constituíam em aspectos que devessem ser dissociados, muito antes pelo contrário. Ambos remeteram à junção das preocupações profissionais com a literatura e a arte, de um lado, e o compromisso político do autor, de outro, essa dupla instância que conferiria aos escritores e artistas também a legitimidade de intelectuais (GILMAN, 2003, p. 72-73). Na verdade, em uma conjuntura histórica que envolvia Guerra Fria, pós-Revolução Cubana e ditaduras na América Latina, a reflexão sobre os assuntos políticos e a intervenção prática no espaço público, por parte dos escritores e críticos latino-americanos ligados às esquerdas, tornou-se praticamente inevitável. ${ }^{13}$

Ainda por esse viés, mas ressaltando um sentindo extremo, novamente Fernando Alegría foi quem nos apresentou uma interpretação de caráter ainda mais premente a respeito da criação artística diante dos crimes, muitos deles fatais, contra os direitos

\footnotetext{
${ }^{12}$ Filiado ao Partido Comunista de Chile, Víctor Jara foi um dos principais expoentes da Nueva Canción Chilena, movimento artístico-político amplo, complexo e diversificado no que diz respeito às experimentações das formas das canções, das composições musicais e dos instrumentos utilizados, mas que adquiriu uma unidade "en la perspectiva ética frente a la injusticia y la miseria, un movimiento solidário en la convicción de que se vivía en un sistema injusto no solo en Chile sino en toda América Latina" (SUBERCASEAUX, 2011, p. 233). Sobre o compromisso social dos artistas que integraram a Nueva Canción Chilena, bem como a valorização e a retomada do folclore e da cultura popular chilena que eles empreenderam por um viés político de esquerda, ver o artigo DONOSO FRITZ (2008).

${ }^{13}$ Apresenta-se imperioso destacarmos que o debate acerca do engajamento do intelectual no âmbito político latino-americano não consistiu em prerrogativa da década de $1960 \mathrm{em}$ diante. Ele esteve especialmente presente nos anos 1920, período em que ideias referentes à revolução, à libertação nacional e ao anti-imperialismo mantiveram-se candentes, pautadas por matizes ideológicos variados. A esse respeito, ver: FUNES (2006).
}

\title{
GANPHLAC
}

Revista Eletrônica da ANPHLAC, ISSN 1679-1061, №. 19, p. 152-185, jul./dez., 2015. http://revista.anphlac.org.br 
humanos provocados pelas ditaduras do Cone Sul. Em sua crítica voltada para a produção fílmica Prisioneros Desaparecidos, de 1979, do cineasta chileno exilado Sergio Castilla, ${ }^{14}$ o diretor de Literatura Chilena en el Exilio enfatizou a função vital da criação artística diante da repressão e violência política, comparando-a com o papel do escritor latino-americano. Para exemplificar, ele citou as obras Cría Ojos, do argentino naturalizado chileno Ariel Dorfman, e Pedro y el Capitán, do uruguaio Mario Benedetti:

Se dirá que el tema de Sergio Castilla es 'la tortura' o 'la represión o 'la violencia fascista' $\mathrm{y}$, en cierto modo, con estas palabras se describirá correctamente su último film 'Prisioneros Desaparecidos'. No se definirá, sin embargo, el conflicto esencial y profundo que lo preocupa. Me parece que Castilla, así como los escritores latinoamericanos que han tratado la tortura en obras recientes [Ariel Dorfman e Mario Benedetti], miran frente a frente un dilema cuyas consecuencias desbordan el caso político circunstancial. Defender la vida propia ante el ataque de los violadores de cuerpos y almas puede ser una manifestación militante de nuestra conciencia política, pero también, y muy particularmente, puede ser un acto de discernimiento destinado a escoger la razón y el método para derrotar a la muerte (ALEGRÍA, 1980, p. 17).

Nessa visão, Alegría defendeu a responsabilidade vital dos intelectuais na criação artística e literária, reforçando seu posicionamento sobre a junção da arte com a política, centrais para a sobrevivência dos próprios intelectuais latino-americanos, sobretudo de seus compatriotas chilenos, se tomarmos em conta a conjuntura histórica marcada pelo terrorismo de Estado em que se apresentava o Chile. ${ }^{15}$

${ }^{14}$ O filme foi coproduzido pelo Instituto Sueco del Cine, país europeu no qual Sergio Castilla encontrava-
se exilado, e pelo Instituto Cubano de Arte e Industria Cinematográficos (ICAIC), vinculado à instituição
cultural Casa de las Américas, criada em Cuba após a Revolução de 1959. Resumidamente, o filme encena,
em forma de um relato, os acontecimentos que ocorreram durante uma semana em uma casa de torturas no
Chile, durante a ditadura de Augusto Pinochet. Nas palavras de Diana Maritza Alzate Mejía, "durante el
largometraje se ponen en escena los dramas de la tortura física, la prisión, el abuso, la tortura psicológica y
la desaparición forzada de la que fueron víctimas la gran mayoría de los prisioneros que sufrieron la
fatalidad de ser recluidos en estos centro o casas de humillación y constante transgresión de los Derechos
Humanos" (ALZATE MEJÍA, 2013, p. 65).
${ }^{15}$ Nos países latino-americanos, partindo do pressuposto da pátria como unidade e de todo o conjunto de
valores cívicos que isso implicava, a Doutrina de Segurança Nacional (DSN) lançou mão, na aplicação de
seus princípios, da violência de Estado, configurando-se, por vezes, em terrorismo de Estado, sob a
justificativa de defender a democracia dos inimigos internos (subversivos), identificados, genericamente,
com o comunismo. De acordo com Enrique Serra Padrós (2008, p. 159), entre as modalidades do Terror de
Estado aplicadas pelas ditaduras do Cone Sul, guardando as especificidades de cada país, salienta-se o uso
da tortura, a presença de esquadrões da morte, os desaparecimentos e a internacionalização do sistema
repressivo através da Operação Condor. Jorge Tapia Valdés explica que a divulgação teórica inicial da DSN
no Chile foi levada a cabo por grupos civis de extrema direita, com finalidade política. Nesse sentido, como GANPHLAC

Revista Eletrônica da ANPHLAC, ISSN 1679-1061, №. 19, p. 152-185, jul./dez., 2015. http://revista.anphlac.org.br 
Do ponto de vista de colaboradores de outras nacionalidades, o cubano Roberto Fernández Retamar, diretor da revista Casa de las Américas, ${ }^{16}$ participou das Jornadas Salvador Allende e ressaltou, elogiosamente, em discurso reproduzido em Literatura Chilena en el Exilio, o fato de muitos intelectuais chilenos, em seu exílio forçado, prosseguirem no exercício de suas atividades como pesquisadores e criadores culturais. Nesse sentido, Fernández Retamar (1978, p. 27-28), citando Literatura Chilena en el Exilio, destacou como verdadeiro ato de atuação pública dos intelectuais a criação, no exílio, de "empresas culturales", como as revistas, nas quais eles próprios pudessem participar e ver suas obras promovidas. Ao longo do seu discurso, Fernández Retamar, um dos principais intelectuais cubanos defensores e promotores da Revolução de 1959, buscou solidarizar-se, em nome do povo de Cuba, com as dificuldades sofridas pelos chilenos durante a ditadura de Augusto Pinochet, denominada por ele de "fascista".

A participação de Roberto Fernández Retamar nas Jornadas Salvador Allende e na revista Literatura Chilena en el Exilio explicitou os vínculos ideológicos e políticos entre os intelectuais chilenos exilados e as esquerdas da América Latina. De maneira mais evidente, faz-se importante trazer à tona que, junto às ideias normativas, veiculadas nas críticas literárias, nos ensaios e nos discursos sobre como deveriam se posicionar os escritores envolvidos com a causa chilena, estiveram presentes pressupostos inseridos na linguagem e no imaginário das culturas políticas comunista e socialista no Chile. Como apresentamos inicialmente, a revista Literatura Chilena en el Exilio traçou seu

o autor expôs, antes e depois do golpe militar de 1973, “los esfuerzos más sistemáticos e permanentes fueron realizados por el Instituto de Estudios Generales, una organización inspirada y financiada por la CIA", a agência de inteligência dos Estados Unidos (TAPIA VALDÉS, 1980, p. 126). A DSN, no Chile, "fue objeto de amplia propaganda [...] en los últimos meses del gobierno de Allende, y tiene relación directa con las razones que, según la Junta Militar Chilena, justificaban el derrocamiento del Presidente Allende" (TAPIA VALDÉS, 1980, p. 128).

${ }^{16}$ Sucedendo à direção de Antón Arrufat (1960-1965), Roberto Fernández Retamar assumiu o cargo de diretor da revista Casa de las Américas cinco anos após sua criação, permanecendo até 1989. Reassumiu o impresso em 1991. Como apontou Adriane Vidal Costa (2013, p. 48-52), a figura de Fernández Retamar foi central para a criação de uma rede intelectual latino-americana de esquerda a partir da revista. Como diretor, ele procurou agregar, por meio do impresso, intelectuais renomados como Julio Cortázar, Ángel Rama, Vargas Llosa e Mario Benedetti (os quatro escreveram na revista e integraram seu Conselho de Redação), além dos próprios cubanos, tais como José Lezama Lima e Alejo Carpentier. Foi também sob a direção de Roberto Fernández Retamar que Casa de las Américas teve uma mudança significativa em sua política editorial, tornando-se cada vez mais alinhada aos preceitos da Revolução Cubana. Para maiores informações sobre a revista, consultar: MOREJÓN ARNAIZ (2004).

\section{GANPHLAC}

Revista Eletrônica da ANPHLAC, ISSN 1679-1061, N. 19, p. 152-185, jul./dez., 2015. http://revista.anphlac.org.br 
editorialismo programático calcada em um viés político de esquerda, o que se percebe através dos intelectuais que nela escreveram e na veia crítica de seus textos. A seguir, poderemos compreender como se deu o debate na revista em torno da relação entre o compromisso político dos escritores/intelectuais e os ideários de esquerda no Chile, sobretudo aqueles de franca relação com a experiência chilena da UP.

\title{
A resistência política dos intelectuais e os valores socialista e comunista no Chile
}

No já mencionado discurso de Fernando Alegría proferido durante as Jornadas Culturales Salvador Allende, o intelectual chileno posicionou-se da seguinte maneira:

\begin{abstract}
Hoy más que nunca la causa de la libertad democrática y la defensa de los derechos humanos exigen de todos los chilenos conscientes una actitud unitaria y combativa. [...] Por el pueblo de Chile, por su clase trabajadora y campesina, con sus profesionales y estudiantes, con todos los hombres que se juegan enteros en Centro y Sudamérica en lucha a muerte contra el imperialismo y las dictaduras gorilas, por el pueblo en México que hoy nos acoge, por el pueblo en Cuba, que nos inspira y nos apoya, por el pueblo de Nicaragua en su heroica resistencia contra el despotismo de Somoza, hagamos de este homenaje a Salvador Allende una gran jornada victoriosa contra el fascismo (ALEGRÍA, 1978, p. 24).
\end{abstract}

Fernando Alegría referiu-se à solidariedade do México, país que sediou as Jornadas, e o recíproco apoio dos chilenos ao povo mexicano e a causas urgentes à esquerda, como os desdobramentos da Revolução Cubana e o candente processo revolucionário na Nicarágua.

A adesão à luta dos chilenos no exílio muito se explica pelo prestígio, no exterior, que adquiriu Salvador Allende - e seu governo à frente da UP - junto às esquerdas, bem como a solidariedade que suscitou por parte da comunidade internacional, em razão da brutalidade do golpe militar em setembro de 1973 e da morte do então presidente socialista no palácio La Moneda. Esses fatores, acrescidos das violações aos direitos humanos cometidas pela ditadura, implicaram, por conseguinte, no rechaço imediato que sofreu a Junta Militar por instituições e governos de distintos países.

Ainda no que tange ao discurso de Fernando Alegría, a ênfase na luta unitária contra a ditadura, por parte dos intelectuais, sem conflito de interesses, insistentemente

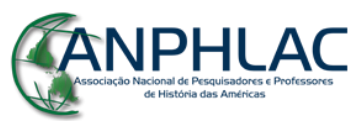

Revista Eletrônica da ANPHLAC, ISSN 1679-1061, №. 19, p. 152-185, jul./dez., 2015. http://revista.anphlac.org.br 
apregoada em sua fala e, não por acaso, nos editoriais de Literatura Chilena en el Exilio desde seu primeiro número, pode ser interpretada como uma espécie de resguardo ao "trauma" referente à divergência de objetivos e estratégias políticas da esquerda chilena durante a experiência da Unidade Popular, o que em muito contribuiu para o insucesso da "via chilena ao socialismo". ${ }^{17}$ Essa interpretação se baseia no fato de que, em grande medida, os problemas da esquerda chilena durante o governo de Salvador Allende teriam sido transplantados para o exílio junto aos intelectuais chilenos desterrados, grande parte deles ligados aos partidos que compuseram a Unidade Popular. A despeito dessa constatação, tais divergências político-ideológicas entre os partidos que integraram a UP não deram margem a debates programáticos explícitos na revista Literatura Chilena en el Exilio, até pela característica cultural desse impresso, não se constituindo em um periódico oficial de determinada interpretação política. Sobressaiu, em suas páginas, a veiculação de personagens e ideias que, de certa maneira, foram pontos comuns nos discursos dos partidos de esquerda durante o governo Allende, com destaque para os partidos comunista e socialista chilenos.

\footnotetext{
${ }^{17}$ A Unidade Popular, enquanto coalizão política de esquerda, tinha como eixos o Partido Comunista (PC) e o Partido Socialista (PS). Contudo, abrigou também em sua composição a Ação Popular Independente (API), os Radicais (PR), o Movimento de Ação Popular Unificado (MAPU) e o Partido Social-Democrata (PSD) (AGGIO, 2002, p. 15). Sobre o golpe militar no Chile, Alberto Aggio analisa, prioritariamente, os conflitos políticos internos do governo da Unidade Popular, decorrentes, segundo o autor, da heterogeneidade de sua composição política à esquerda. Para Aggio, a ação política e de governo da UP não conseguiu expressar-se consensualmente através de um projeto claro de construção do socialismo pela via institucional-democrática, aspecto central do seu programa. A identificação integral entre ambas democracia e socialismo - "[...] acabou por não se configurar numa linha política clara e hegemônica nem no interior do governo nem entre os partidos que o apoiavam [...]" (AGGIO, 2002, p. 153). Soma-se a isso, a forte oposição sofrida no parlamento por meio da Democracia Cristã e do Partido Nacional, travando institucionalmente o governo de Salvador Allende. Junto à ausência de um claro projeto que unificasse os partidos de esquerda que compunham a UP, a direita chilena pressionava o governo através de forte campanha ideológica visando a quebra de sua legitimidade diante da sociedade (AGGIO, 2002, p. 29-31). O golpe de Estado ocorreu em meio a esse cenário de fragilidade política da UP e união entre as forças sociais da direita chilena e as Forças Armadas do país. Estas justificaram sua ação expondo a necessidade de restaurar a unidade nacional e retirar o Chile do "caos econômico" e da "ilegitimidade política" sob o governo dos "marxistas", denominação aplicada de modo pejorativo de maneira a conotar supostos danos materiais e morais provocados por um governo de esquerda, como a UP. Ver, ainda, no que tange às negociações, às ambiguidades e às contradições geradas no processo de construção do projeto da Unidade Popular pelas distintas perspectivas político-ideológicas dos partidos da esquerda marxista, CASALS ARAYA (2010). Sobre as contradições no interior da UP na tentativa de aplicação da "vía chilena al socialismo", sugerimos: MOULIAN (2006).
}

\section{CANPHLAC}

Revista Eletrônica da ANPHLAC, ISSN 1679-1061, №. 19, p. 152-185, jul./dez., 2015. http://revista.anphlac.org.br 
No discurso proferido por Fernando Alegría, importa-nos perceber questões para além da defesa das liberdades democráticas e dos direitos humanos no Chile e nos países do Cone Sul acometidos pelas ditaduras militares. Junto à função dos escritores chilenos no exílio, salientamos a veiculação de expressões, sujeitos e lugares correspondentes aos ideais comuns difundidos pelas esquerdas, como a valorização das classes trabalhadoras chilenas urbanas e do campo, a significação conferida aos processos revolucionários em Cuba e na Nicarágua, e, por fim, o anti-imperialismo.

A veiculação de valores das esquerdas possuiu significativa projeção em Literatura Chilena en el Exilio. A revista difundiu, em especial, imagens e representações de dois personagens que, na ótica de seus intelectuais colaboradores, simbolizaram a resistência e o compromisso político do intelectual de esquerda chileno em relação ao golpe militar no país, quais sejam, Salvador Allende e Pablo Neruda.

Sobre este último, somente por parte do crítico literário chileno Guillermo Araya, foram quatro artigos publicados em Literatura Chilena en el Exilio, o que por si só já explicita a relevância atribuída ao poeta chileno pela revista. ${ }^{18}$ De maneira geral, tanto o teor politizado de sua obra, sobretudo em Canto General, quanto a figura do poeta como escritor e político comunista engajado nos problemas sociais do Chile e da América Latina foram ressaltados nas críticas literárias de Araya, que apareceu, em um primeiro momento, como principal crítico da produção poética de Pablo Neruda. De suas críticas, vejamos uma na qual Guillermo Araya analisou especialmente Canto General. Em Lo Epico del Canto General de Neruda, o teor de sua reflexão sobre essa obra recaiu no caráter político e ideológico-marxista fortemente presente nela, segundo Araya. Por essa perspectiva, o autor apresentou o posicionamento crítico de Pablo Neruda em relação ao imperialismo dos Estados Unidos, visto como principal inimigo do desenvolvimento econômico e social da América Latina. No caminho inverso, Araya ressaltou, em Canto General, o louvor de Neruda ao Partido Comunista de Chile (PCCh), ao qual o poeta

\footnotetext{
18 ARAYA, Guillermo. Etapas en la obra de Pablo Neruda. Literatura Chilena en el Exilio, Los Angeles, n. 6, 1978, p. 2-4; Estructura del Canto General de Neruda. Literatura Chilena en el Exilio, Los Angeles, n. 7, 1978, p. 2-5; Lo Epico del Canto General de Pablo Neruda. Literatura Chilena en el Exilio, Los Angeles, n. 8, 1978, p. 2-4; El Hombre y la Tierra de América en el Canto General de Neruda. Literatura Chilena en el Exilio, Los Angeles, n. 9, 1979, p. 2-4.
}

\section{BANPHLAC}

Revista Eletrônica da ANPHLAC, ISSN 1679-1061, №. 19, p. 152-185, jul./dez., 2015. http://revista.anphlac.org.br 
chileno pertenceu, e a países e personagens representativos da cultura política comunista no Chile, em especial, a URSS e o líder sindical e fundador do PCCh, Luis Emilio Recabarren:

[...] En Canto General, el punto de vista es tajantemente ideológico-político. El poeta exalta lo que está en la línea marxista de su visión de la realidad americana y combate y apabulla todo lo que considera enemigo u opuesto a esa postura ideológica. La ideología ocupa en el Canto el lugar que ocupaba la religión en la épica homérica, medieval y renacentista. El poeta expresa reiterada e insistentemente sus convicciones ideológicas. Hay un poema dedicado A mi partido; entre los libertadores de América el más extensamente cantado es Recabarren, fundador del partido comunista chileno [...]; en Que despierte el leñador, gran parte de esta serie es una exaltada alabanza de la Rusia socialista, y en muchos otros lugares del Canto la ideología comunista del poeta se objetiva en poemas esparcidos en diversas series o en trozos de poemas [...] (ARAYA, 1978, p. 3).

Em que pese a importância de Neruda para a revista, certamente o personagem que mais ênfase recebeu, por parte de Literatura Chilena en el Exilio, no sentido de destacá-lo enquanto símbolo maior da resistência ao golpe militar de 1973, foi o presidente socialista Salvador Allende. O mencionado evento Jornadas Culturales Salvador Allende, que se realizou em homenagem aos 70 anos de nascimento do expresidente chileno, não foi apenas patrocinado, mas, principalmente, divulgado por Literatura Chilena en el Exilio em sua edição de $n^{\circ}$ 8. Boa parte dos escritores e críticos que compuseram seu conselho editorial e/ou colaboraram frequentemente com a revista, como Fernando Alegría, David Valjalo, Jaime Concha, Naín Nómez e Poli Délano, organizaram os debates referentes à literatura de resistência política durante as Jornadas. Foi comum, nos discursos e nas ponencias desse evento publicados na revista, referências a Salvador Allende, mesmo não sendo ele o objeto a ser debatido nas mesas de discussão das Jornadas Culturales. Assim, Fernando Alegría defendeu a condição de "mártir" da resistência chilena do presidente socialista, que resistiu até a morte no momento em que o palácio presidencial La Moneda foi bombardeado por setores golpistas das Forças Armadas. Tornando-se, portanto, inspiração máxima para os opositores do regime, Salvador Allende, na acepção de Fernando Alegría,

al morir combatiendo el 11 de septiembre de 1973, [...] empezó, en verdad, a vivir y vencer. Eso que él mismo llamó sus 'últimas palabras' no es tanto un renacer desde el humo y las llamas de la patria vieja, como el comienzo de una

\section{GANPHLAC}

Revista Eletrônica da ANPHLAC, ISSN 1679-1061, №. 19, p. 152-185, jul./dez., 2015. http://revista.anphlac.org.br 
etapa histórica en que el pueblo probará sus armas y el temple de su resistencia en la reafirmación de lo que ha sido, es y siempre será suyo: el derecho a la libertad. Por eso celebramos los 70 años de vida del Presidente Allende en el tono y el sentido que alumbran su visión de las grandes alamedas: sin quejas y sin dudas, sin nostalgias vanas ni ensoñaciones remotas, más bien con la tranquila alegría de las victorias logradas en la resistencia y el exilio, con la firme e implacable voluntad del regreso y la seguridad de un triunfo permanente (ALEGRÍA, 1978, p. 22).

As "últimas palavras" de Salvador Allende, mencionadas por Fernando Alegría em referência ao discurso do presidente realizado em La Moneda no instante em que os militares avançavam sua ofensiva para destituí-lo do comando, foram, números antes, publicadas em Literatura Chilena en el Exilio - em sua edição de número 4, como citamos anteriormente. Transmitido pela rádio estatal Magallanes, às 9h10 da manhã de 11 de setembro de 1973, destacamos alguns trechos do notório discurso de Allende, nos quais se evidenciam sua resistência:

\footnotetext{
Ante estos hechos, sólo me cabe decir a los trabajadores:

Yo no voy a renunciar.

Colocado en un tránsito histórico, pagaré con mi vida la lealtad del pueblo y les digo que tengo la certeza que la semilla que entregamos a la conciencia digna de miles y miles de chilenos no podrá ser cegada definitivamente.

Y tienen la fuerza, podrán avasallar, pero no se detienen los procesos sociales ni con el crimen ni con la fuerza.

La historia es nuestra y la hacen los pueblos.

$[\ldots]$

Trabajadores de mi patria:

Tengo fe en Chile y su destino. Superarán otros hombres de Chile, este momento gris y amargo donde la traición pretende imponerse. Sigan ustedes sabiendo que mucho más temprano que tarde, de nuevo se abrirán las grandes alamedas por donde pase el hombre digno para construir una sociedad mejor. iViva Chile!

iViva el pueblo!

iVivan los trabajadores!

Estas son mis últimas palabras.

Y tengo la certeza de que mi sacrificio no será en vano. Tengo la certeza de que por lo menos será una lección moral que castigará la felonía, la cobardía y la traición (ALLENDE, 1977, p. 2).
}

As publicações, em Literatura Chilena en el Exilio, dos dois últimos discursos analisados por nós, ambos sob o viés da resistência intelectual e política ao golpe, representam bem como Salvador Allende foi retomado pela revista. Embora não tenhamos constatado uma vinculação política e partidária explícita por parte desse

\section{GANPHLAC}

Revista Eletrônica da ANPHLAC, ISSN 1679-1061, №. 19, p. 152-185, jul./dez., 2015. http://revista.anphlac.org.br 
impresso, fica claro seu pertencimento às esquerdas chilenas por duas questões centrais que compuseram seu editorialismo programático: o perfil político de seus editores e principais colaboradores que participaram, boa parte deles, da experiência de governo da Unidade Popular; bem como os conteúdos de seus textos, nos quais foram difundidos símbolos, ideias e personagens, como Salvador Allende, que fazem parte de um imaginário das esquerdas no Chile, especialmente o que se encontra associado à UP.

Para os colaboradores de Literatura Chilena en el Exilio, a figura do intelectual foi peça fundamental na resistência e na elaboração de projeções políticas alternativas ao regime autoritário chileno. No caso dos escritores, evidentemente que a literatura consistiu no seu principal instrumento de intervenção pública. Para tal, portanto, foi necessário que se refletisse também acerca da função da literatura chilena diante da repressão. Assim, não por acaso, dentre os gêneros literários mais discutidos pela crítica literária e pelo ensaio publicados na revista estiveram os testimonios, tanto em prosa como em poesia. Tratou-se de um gênero de longa tradição no Chile, mas que, em virtude do golpe militar, adquiriu novas projeções temáticas e estéticas, estreitamente acordes com o papel político dos escritores/intelectuais instado na revista.

\section{O testemunho como arma: literatura e resistência política}

Em Literatura Chilena en el Exilio ${ }^{\circ}$ 5, Juan Armando Epple publicou uma importante crítica literária denominada Esa literatura que surge de un cerco de púas. Nela, Epple analisou a literatura de testemunho chilena produzida após o golpe de 1973. O título do texto remete deliberadamente à obra Cerco de Púas, de Anibal Quijada, publicada em 1977 e ganhadora do Prêmio Casa de las Américas pelo gênero testimonio. Refere-se também, de maneira mais ampla, aos demais textos surgidos do interior de um cerco de pontas agudas (púas), ou seja, de uma prisão ou "campo de concentração" chileno. Podemos expandir a interpretação e pensar em uma alusão à literatura criada a partir de situações adversas e limites impostas pelas forças de repressão da ditadura militar pinochetista, incluindo, nesse sentido, a condição do exílio.

Além do testimonio de Aníbal Quijada, Juan Armando Epple destacou a publicação de outros dois livros que, a seu ver, transformaram-se em paradigmas da

\section{GANPHLAC}

Revista Eletrônica da ANPHLAC, ISSN 1679-1061, N. 19, p. 152-185, jul./dez., 2015. http://revista.anphlac.org.br 
literatura testemunhal chilena produzida no exílio e que fizeram referência à fase mais repressiva da ditadura chilena, quais sejam: Tejas Verdes (1974), de Hernán Valdés, e Prisión en Chile (1975), de Alejandro Witker. Os três livros, como afirmou Epple, recorreram a experiências pessoais de sobreviventes da repressão institucionalizada em distintos "campos de concentração". Desenvolveram uma radiografia inicial da ditadura de Augusto Pinochet, relatando o que sucedeu em três pontos distintos do Chile - a região austral (Punta Arenas, no "campo de concentração" de Isla Dawson - Anibal Quijada), o centro do país (Tejas Verdes - Hernán Valdés) e o norte (prisão de Chacabuco Alejandro Witker). Segundo o crítico literário chileno, as obras mencionadas se situam em uma categoria especial que é a literatura-testimonio, que "[...] cifra su valor y sus limites en la autenticidad documental de la experiencia vivida [...]", diretamente vinculada, portanto, à memória individual e coletiva, o que, segundo Epple, “[ ...] no impide que, desde sus limites, irradien la fuerza y la belleza que se puede encontrar en cualquier obra de ficción bien hecha, y superando a muchas de ellas [...]” (EPPLE, 1978, p. 7-8).

Aqui, claramente, percebemos que Juan Armando Epple fez uma espécie de defesa do testimonio enquanto gênero literário, que não necessariamente perderia sua qualidade, enquanto criação formal, em função do seu teor altamente politizado. Ao contrário, o crítico apontou para o fortalecimento do testemunho no Chile, sobretudo a partir do golpe de 1973, por razões óbvias. Todavia, em sua perspectiva, “[...] este tipo de literatura no es nuevo en Chile, como tampoco es nuevo el tipo de experiencias que la origina [...]" (EPPLE, 1978, p. 8). Não obstante, Epple enfatizou que a produção de testimonios cresceu vertiginosamente à proporção da repressão e da violência implantadas no país a partir do 11 de setembro de 1973, ganhando projeção internacional sem precedentes.

Quando pensamos na literatura de testemunho, coloca-se a necessária distinção entre o testemunho da Shoah, termo cunhado em substituição à palavra holocausto, e os testimonios forjados em nosso contexto latino-americano. Um importante estudo que alerta para a necessidade dessa diferenciação é o de Valeria de Marco (2004), no qual a autora nos mostra, amparada na atividade da crítica literária correspondente, a existência,

\section{BANPHLAC}

Revista Eletrônica da ANPHLAC, ISSN 1679-1061, №. 19, p. 152-185, jul./dez., 2015. http://revista.anphlac.org.br 
no âmbito estritamente teórico, dessas duas grandes concepções de literatura de testemunho, a da Shoah e a latino-americana, bem como o fato de que tais vertentes não dialogam entre si.

Os testemunhos da Shoah inserem-se no contexto do pós-Segunda Guerra Mundial, e os debates a seu respeito pela crítica correspondente evidenciam a tensão, por vezes o impasse, da impossibilidade de reconstrução, do ponto de vista do relato na escrita, de vivências pessoais e coletivas que estiveram e estão irremediavelmente marcadas pela catástrofe e pelo trauma. ${ }^{19}$ Tangente à crítica literária voltada para a literatura de testemunho na América Latina, nota-se, segundo Valeria de Marco (2004, p. 45), o predomínio de duas acepções dessa categoria que têm em comum a vinculação entre produção literária e o resgate da história contemporânea.

Uma dessas correntes, que emergiu na década de 1980, seria a que tem se desenvolvido, principalmente, no espaço acadêmico norte-americano, e que dialogou, de forma sistemática, com os estudos culturais. A partir do testemunho oral de Rigoberta Menchú, recolhido, comentado e organizado em livro, em 1983, por Elizabeth BurgosDebray, desenvolveu-se um tipo de literatura testemunhal no qual um letrado, espécie de voz autorizada socialmente, teria a incumbência de "recolher a voz do subalterno, do marginalizado, para viabilizar uma crítica e um contraponto à 'história oficial'”. Ao letrado, editor/organizador do texto, caberia uma postura política de solidariedade para com o outro, devendo reproduzir fielmente seu discurso, que se legitimaria por ter sido "representativo de uma classe, uma comunidade ou um segmento social amplo e oprimido" (MARCO, 2004, p. 46).

A outra corrente de testemunhos latino-americanos seria aquela em que a crítica literária pautou-se na interpretação e no "exame de textos que, construídos a partir de múltiplas combinações de discursos literários, documentais ou jornalísticos, registram e interpretam a violência das ditaduras da América Latina durante o século XX” (MARCO, 2004, p. 46). Assim, não temos dúvidas em afirmar que a crítica literária presente em

\footnotetext{
${ }^{19}$ No Brasil, nessa linha de reflexão acerca dos testemunhos, indicamos os trabalhos de Márcio SeligmannSilva, em especial, SELIGMANN-SILVA, Márcio (org.). História, Memória e Literatura: o testemunho na era das catástrofes. Campinas: Editora da Unicamp, 2003.
}

\section{GANPHLAC}

Revista Eletrônica da ANPHLAC, ISSN 1679-1061, №. 19, p. 152-185, jul./dez., 2015. http://revista.anphlac.org.br 
Literatura Chilena en el Exilio ateve-se a esta última corrente explicativa acerca da literatura testemunhal.

A possibilidade de narrar, a posteriori, a trágica experiência da repressão no Chile, por parte da literatura de testemunho, adquiriu, sobretudo na segunda metade dos anos 1980, um sentido, em geral, mais metafórico na utilização da linguagem e não tão explícito em relação à ditatorial, à censura e à repressão, resultando na diversificação cada vez maior dos testimonios (STREJILEVICH, 2006). Todavia, em razão do nosso recorte temporal, interessa-nos a crítica literária que tematizou sobre os testemunhos dos anos 1970, para a qual, dado o caráter de urgência e muitas vezes vital que a literatura adquiriu naquele contexto chileno, não se admitia um tipo de linguagem que não se expressasse de maneira simples, direta e explícita no que diz respeito à memória e à consequente denúncia à violência política das forças repressivas da ditadura chilena.

A resenha crítica do livro La Cienaga (1975), de Matilde Ladron de Guevara, feita pelos editores de Literatura Chilena en el Exilio, evidenciou a importância dada à linguagem viva e direta da literatura de testemunho naquele período de ditadura e de exílio. Os estritos cânones literários, bem como a maneira padronizada e acadêmica de avaliar a qualidade textual e estética de uma obra, não serviriam de parâmetro para a análise do tipo de literatura que surgia como resposta às condições de violência e de repressão política. Aqui, a crítica pareceu separar o leitor comum dos próprios críticos literários que não reconheceriam no livro de Ladron de Guevara, necessariamente, virtudes técnicas da escrita. Mas, a partir da resenha, cabe a indagação: qual a real importância da qualidade formal da escrita diante da sua utilização premente enquanto forma de resistência e, mesmo, podemos dizer, de sobrevivência? Seria realmente necessária a exigência de qualidades estéticas nos testimonios ou a missão principal desses textos consistiria, naquele contexto, em denunciar as atrocidades contra os direitos humanos cometidas pela ditadura? A resposta a essas indagações encontra-se na citação abaixo, extraída da resenha do livro de Matilde Ladron de Guevara, resposta esta que parece fazer-se presente em grande parte das análises críticas publicadas em Literatura Chilena en el Exilio a respeito da literatura produzida sob aquelas condições históricas:

\section{GANPHLAC}

Revista Eletrônica da ANPHLAC, ISSN 1679-1061, №. 19, p. 152-185, jul./dez., 2015. http://revista.anphlac.org.br 
Se comprende el amplio interés que ha despertado esta vigorosa novela de Matilde Ladrón de Guevara. Escrita bajo el fuego cruzado de la violencia política chilena de 1973, sorprende por su fondo documental lleno de apasionantes detalles e inesperadas revelaciones. El lector de la literatura chilena en el exilio verá aquí una novela en clave: identificará personajes, comprobará heroísmos y cardas, seguirá de cerca a la autora en su dolorosa y airada búsqueda de la razón del drama. El crítico literario, por su parte, verificará una vez más cuán difícil es el arte del testimonio novelesco. Porque, naturalmente, Matilde Ladrón de Guevara está demasiado cerca de la tragedia. Describe con pericia, pero también protesta, denuncia y condena con elocuencia. Su voz, a ratos lírica y, a ratos, tribunicia e histórica, es la voz de una mujer que reacciona con valentía y dignidad herida por los golpes de la dictadura. Sus personajes son más que individuos. Representan el sufrimiento de un pueblo, el estoicismo de quienes caen y se levantan para seguir combatiendo. No es posible aplicarle a esta obra estrictos cánones literarios. ¿Cómo pedirle técnica a un alegato de vida o muerte? Estilo, si lo tiene, ejemplar, vibrante, muy de acuerdo con la riqueza de su carrera como poeta y prosista (LITERATURA CHILENA EN EL EXILIO, 1978, p. 36).

Em um sentido muito próximo a essa perspectiva, Epple publicou sua resenha crítica do livro Las Malas Juntas (1978), do escritor chileno, exilado no Canadá, Leandro Urbina, em Literatura Chilena en el Exilio, $\mathrm{n}^{\circ} 14$ - última edição da revista com este nome, como apontamos. Ao refletir sobre a obra, Epple observou a importância da linguagem intensa, natural, direta e precisa dos relatos presentes na literatura de Urbina. Segundo ele, o mérito literário de Leandro Urbina era possuir uma linguagem "alejado de tentaciones retóricas y de preocupaciones por acrecentar la figura del narrador, buscando en cambio despejar el camino para dejar fluir con mayor nitidez la historia" (EPPLE, 1980, p. 31). Para o crítico chileno, portanto, a importância da obra de Leandro Urbina consistia na capacidade que o escritor possuía de se aproximar, com sua trama ficcional de corte testemunhal, da experiência do vivido,

en este íntimo acto de rescatar el mundo inmediato a través de la memoria, la base necesaria para ir descubriendo la realidad. Contar cómo fueron las cosas es, nuevamente, un requisito para que esa lectura significativa del mundo que es la literatura tenga una base firme (EPPLE, 1980, p. 31).

Em sentido similar, também se expressou sobre a obra de Leandro Urbina o escritor e poeta chileno Jorge Narváez, para quem a linguagem dos contos de Las Malas Juntas, "dentro del estilo del realismo dominante, es suelto y coloquial. [...] Nos hace

\section{CANPHLAC}

Revista Eletrônica da ANPHLAC, ISSN 1679-1061, №. 19, p. 152-185, jul./dez., 2015. http://revista.anphlac.org.br 
palpar la realidad chilena y despierta la conciencia sobre ella [...]" (NARVÁEZ, 1979, p. $35)$.

Essa pretensa ideia do estatuto da verdade na obra literária foi uma tônica nos debates sobre a função da literatura na revista. Pensamos que esse tipo de interpretação forjou-se de maneira coerente com a trajetória de Literatura Chilena en el Exilio enquanto bem cultural de resistência política no exílio, fazendo todo sentido, portanto, naquela conjuntura histórica específica. Contudo, entendemos também que é possível problematizar, embora não seja objeto de nossa reflexão neste texto, até que ponto a revista não poderia ser um meio ainda mais rico de veiculação da literatura chilena no exílio se fosse mais flexível quanto à seleção e à publicação de textos de variados matizes formais e temáticos.

A interpretação do diretor da revista quanto à literatura testemunhal não deixou dúvidas a respeito de sua posição em relação a essas questões apontadas por nós. Sobre os testemunhos surgidos a partir de setembro de 1973, Fernando Alegría afirmou que "la severidad espeluznante de los hechos contados es tan filosa que no admite regodeos retóricos de ninguna clase" por parte dos escritores. Não se deveria, referiu-se Alegría (1978, p. 34), cair na literatura pela literatura. Tal argumentação foi feita a partir da análise que desenvolveu do livro publicado pelo jovem escritor chileno Ilario Da (pseudônimo), Relato en el frente chileno, de 1977, cuja crítica foi publicada na seção Libros - dedicada às resenhas literárias - de Literatura Chilena en el Exilio em 1978, ${ }^{\circ}$ 7. Fernando Alegría enfatizou o talento de um escritor que, surgido no contexto ditatorial em razão de se opor ao status quo político através da literatura, conseguiu aliar, em sua obra testemunhal, técnica literária com compromisso político, junção esta necessária, em sua visão, naquele momento histórico:

llario Da, a los 21 años, ha escrito un libro memorable, clásico, a la altura de los más conmovedores documentos literarios antifascistas del siglo veinte. Da es un narrador nato, que maneja los resortes de la estructura novelesca con maestría instintiva, que nunca se deja dominar por el lenguaje y que va creando un suspense irresistible, porque de suspense está hecha su vida. [...] llario Da lo dice con sencillez, con arte natural, con todo el poder de la resistencia de quien cayó a los 18 años, fue arrastrado de un campo a otro de torturas, hasta que los conoció todos, soportó cuanto suplicio físico y psicológico le aplicaron los expertos de la contra-insurgencia, y vivió y sobrevivió para contar el cuento

\section{GANPHLAC}

Revista Eletrônica da ANPHLAC, ISSN 1679-1061, №. 19, p. 152-185, jul./dez., 2015. http://revista.anphlac.org.br 
con voz varonil, noble, plena de juventud y confianza en el triunfo final (ALEGRÍA, 1978, p. 34).

Se pretendemos compreender melhor como teria se projetado o editorialismo programático que orientou a seleção, publicação e divulgação, por parte do Conselho Editorial, dos ensaios, da crítica e dos textos literários em Literatura Chilena en el Exilio, entendemos que se faz essencial a interpretação, por Fernando Alegría, da função da literatura. ${ }^{20}$ Assim, para deixar ainda mais explícita sua opinião a respeito, o diretor da revista defendeu que a

[...] Literatura [...] no es solamente un cuerpo de narrativa, dramaturgia, poesía o ensayística, que adquiere su estructura y su ambiente vital por el simple peso de su testimonio creativo. Es algo más, o quizá sea mejor decir, algo diferente. Debe serlo si por creación estética entendemos un modo de comunicar una visión crítica del mundo en que vivimos y la tentación sagrada de actuar sobre ese mundo para deconstruirlo y reconstruirlo de manera que se aproxime a las imágenes en las cuales quisiéramos mirarnos integralmente. Es posible concebir una literatura sin ideología? Me parece dudoso y, acaso, más dudoso aún imaginar a un creador literario que escriba al azar, como decir, siguiendo la dirección de los vientos (ALEGRÍA, 1982, p. 113).

O debate sobre o suposto conflito entre os valores políticos e estéticos na literatura tornou-se frequente nas críticas de Fernando Alegría publicadas em Literatura Chilena en el Exilio. Nelas, como já foi possível perceber em nossas análises e no último trecho supracitado, extraído de outra revista chilena de exílio, Araucaria de Chile, ${ }^{21}$ Alegría não hesitou em apontar para a junção de ambas as possibilidades em razão, como ficou evidente, de não haver uma criação literária estética pura e simples, sem se pautar por vínculos ideológicos. Diríamos mesmo que, dada a conjuntura histórica do Chile após 1973, a função política da literatura, em Fernando Alegría, realçava-se em importância se

\footnotetext{
${ }^{20}$ Destacamos o livro Literatura y Revolución, de Fernando Alegría, como fonte relevante na qual o autor explicitara sua posição a respeito da literatura em vertente próxima à colocada aqui a partir da revista, embora o contexto de produção da obra tenha sido outro, anterior ao golpe militar de 1973. Cf. ALEGRÍA (1971).

${ }^{21}$ Criada em Roma em 1977, Araucaria de Chile, que possuiu circulação trimestral, foi uma revista cultural e política. Tendo como sede inicial a cidade de Paris, a revista foi lançada oficialmente no primeiro trimestre de 1978 e encerrou sua publicação no primeiro trimestre de 1990, com o fim da ditadura chilena, totalizando 48 números publicados ininterruptamente. Foi fundada e dirigida por Volodia Teitelboim e Carlos Orellana, membros do Partido Comunista de Chile. Para maiores informações, ver: SILVA (2009); COELHO NETO; PRATES (2014).
}

\section{CANPHLAC}

Revista Eletrônica da ANPHLAC, ISSN 1679-1061, №. 19, p. 152-185, jul./dez., 2015. http://revista.anphlac.org.br 
confrontada com a velha discussão sobre a possibilidade de compatibilidade entre estética e política. Para Alegría, portanto, pelas leituras que fazemos de suas análises na revista Literatura Chilena, o estético estivera condicionado à instrumentalização da literatura como bem cultural de resistência política à ditadura chilena, embora a questão formal do texto literário, ressalvemos, não fosse desprezada em hipótese alguma por ele.

Sobre a relação entre poesia e política no Chile, ressaltamos o texto de Jaime Concha (Literatura Chilena en el Exilio, $\mathrm{n}^{\circ} 4$ ), no qual ele afirmou que a aproximação do poema com a política consumou-se fortemente através da canção popular chilena, tendo como principais expoentes Violeta Parra, Ángel e Isabel Parra, Patricio Manns e Víctor Jara. Com a ditadura estabelecida pela Junta Militar e o consequente exílio de artistas e poetas, os laços entre poesia e política se estreitaram. Após o golpe de Estado, os poetas chilenos “[...] lucha[ran] por acercarse más y más a la actividad popular, por absorber y revelar el momento histórico que viv[ia] el país [...]" (CONCHA, 1977, p. 13). Concha mencionou os trabalhos de Omar Lara, Waldo Rojas, Gonzalo Millán, Jaime Quezada e Floridor Pérez, afirmando que alguns deles foram feitos prisioneiros no momento do golpe e a maioria encontrou-se exilada. Do exílio, canalizaram suas abordagens para a denúncia à repressão e à violência política no Chile, convertendo seus poemas em verdadeiros testemunhos contra a ditadura.

Nesse sentido, na perspectiva de Paloma Vidal (2004, p. 20), as narrativas literárias do exílio, em geral, estruturaram-se em torno do trauma para construir, a partir dele, uma trama que se encontrou na fronteira entre ficção e testemunho. Nesses textos, aponta a autora, a experiência traumática tende a ser direcionada para temas e questões variadas referentes à solidão, ao corpo, à memória e à violência. Segundo Juan Armando Epple, os escritores no exílio,

\footnotetext{
Frente a la destruición de los fundamentos cotidianos con que se vivía el mundo antes del golpe militar, y ante la necesidad de expresar y darle una significación a las nuevas experiencias vitales [...], acuden a las más variadas formas narrativas, y no con un simple afán de experimentación formal, sino tratando de probar la eficacia de las opciones ofrecidas por el arte de la escritura para encauzar la necesidad expresiva (1981, p. 210).
}

\section{CANPHLAC}

Revista Eletrônica da ANPHLAC, ISSN 1679-1061, №. 19, p. 152-185, jul./dez., 2015. http://revista.anphlac.org.br 
O autor explicou ainda que a literatura chilena no exílio, nesse processo de necessária reflexão das possibilidades expressivas, encontrou caminho para avançar à medida que se manteve intimamente atrelada a seu momento histórico e político. ${ }^{22}$

Posicionamentos relativamente distintos quanto à literatura de resistência política também obtiveram espaço na revista Literatura Chilena en el Exilio. O professor universitário chileno Marcelo Coddou, exilado nos EUA, em crítica literária na qual analisou a narrativa chilena feita no exílio - Narrativa Chilena en el Exilio: Notas de Aproximación -, defendeu a importância de uma literatura política, mas sem que essa condição - ponderou o professor -, prejudicasse a composição estética da obra literária (CODDOU, 1979, p. 8-10). O valor estético da obra não deveria estar, em sua ótica, subjugado à ideologia e à política, muito embora apontasse para a relevância ética do escritor de resistir à ditadura no Chile. No nosso entender, trata-se de uma perspectiva que diferiu, em parte, em relação às ideias literárias e políticas instadas pelos principais críticos que frequentemente escreveram em Literatura Chilena en el Exilio, como Fernando Alegría e Juan Armando Epple. Para estes, a literatura tinha o papel precípuo, naquele momento de repressão política, de resistir e denunciar os crimes contra a humanidade cometidos pela ditadura. Tanto assim que, em suas críticas literárias, valorizaram sobremaneira o testemunho enquanto gênero literário tradicional, válido e certamente necessário no Chile após 1973, enquanto Coddou construiu críticas a esse tipo de literatura ao apontar para o caráter ideológico e meramente reducionista de uma narrativa marcada por "episodios impactantes", de valor estético duvidoso (CODDOU, 1979, p. 33).

Crítica literária semelhante foi feita por Hubert Cornelius ao resenhar o livro Joven narrativa después del golpe, antologia organizada pelo intelectual chileno Antonio Skármeta no exílio. Embora também compreendesse a premência da criação literária próxima à realidade política chilena naquela conjuntura, ao apontar, por exemplo, para uma valorosa literatura que "parece ir emparentándose con el testimonio", Hubert Cornelius acreditava, todavia, que esse compromisso com a realidade tornar-se-ia mais

\footnotetext{
${ }^{22}$ Para mais informações e análises a respeito da literatura produzida no exílio, ver: CYMERMAN (1993); RAMA (1978).
}

\section{GANPHLAC}

Revista Eletrônica da ANPHLAC, ISSN 1679-1061, N. 19, p. 152-185, jul./dez., 2015. http://revista.anphlac.org.br 
eficaz e criador, do ponto de vista da qualidade formal e literária, quando existisse "una fuerza imaginativa dispuesta a ejercer sus fueros, a romper con las limitaciones de las cosas ya establecidas”. Em outras palavras, a literatura não poderia limitar-se ao relato testemunhal, à linguagem simples e direta, mas, sim, construir-se de maneira criativa e com maior "libertad para entenderse con la realidad" (CORNELIUS, 1978, p. 34).

Contudo, predominou na revista a vertente que salientou a necessidade de expressão política do texto literário, do seu compromisso público, superando quaisquer pretensões meramente estéticas para a literatura. A questão formal do texto, que em momento algum fora desprezada pelos autores aqui analisados, acompanharia, obviamente, a renovação e a ressignificação da literatura chilena de resistência política divulgada e promovida pela crítica especializada em Literatura Chilena en el Exilio.

Certamente, a revista participou ativamente da dinâmica desse processo, contribuindo para a consolidação, no contexto ditatorial e de exílio, do gênero testimonio. O escritor guatemalteco Roberto Díaz Castillo, ao analisar a literatura testemunhal no exílio, reconheceu a importância de Literatura Chilena en el Exilio como "frente de lucha y de acusación irrefutable a la tiranía de Pinochet” (DÍAZ CASTILLO, 1979, p. 5). Díaz Castillo direcionou-se à revista como "testimonio del testimonio", tamanha a importância que o impresso concedeu a esse gênero, divulgando amplamente, sobretudo, a literatura de exílio que decorria de "un cerco de púas".

Assim, como considerações finais, defendemos, em concordância com Fernanda Beigel (2003, p. 110), que certos paradigmas da crítica ganham espaço preferencialmente nas revistas culturais, difundindo novas práticas e novos projetos, o que nos permite visualizar correntes literárias que formam parte de um período cultural e político específico. Dessa maneira, ao transportarmos essas perspectivas para a revista Literatura Chilena en el Exilio, reiteramos a ideia de que o impresso contribuiu, sobremaneira, através da crítica veiculada em suas páginas, na promoção e afirmação de uma literatura, criada predominantemente no exílio, que se relacionava fortemente com o político. A literatura de testemunho adquiriu, então, na revista, posição de destaque, dada a ressignificação que esse gênero obteve no âmbito literário chileno após 1973.

\section{CANPHLAC}

Revista Eletrônica da ANPHLAC, ISSN 1679-1061, N. 19, p. 152-185, jul./dez., 2015. http://revista.anphlac.org.br 
$\mathrm{Na}$ mesma medida e diretamente ligado a esse aspecto, a revista realçou a importância política do engajamento dos escritores e artistas na resistência à ditadura militar no Chile. À noção de intelectual veicularam-se valores e ideias presentes nas culturas políticas comunista e socialista, especialmente. O exílio e o caráter oposicionista e combativo dos editores de Literatura Chilena en el Exilio, dos seus colaboradores e das obras analisadas, produzidas sob condições semelhantes, influíram em certa homogeneidade de discursos no interior da revista. Estes foram construídos e mantiveram-se muito bem entrelaçados ao editorialismo programático de Literatura Chilena en el Exilio, pautado pela resistência à ditadura e pela reconstrução de alicerces institucionais democráticos dentro do campo ideológico das esquerdas chilenas, sobretudo aquela que buscou resgatar os principais emblemas e valores da Unidade Popular, incluindo a figura de Salvador Allende.

Acreditamos que tais condutas pró-ativas de resistência por parte de Fernando Alegría e David Valjalo, bem como dos demais escritores, ensaístas e críticos literários chilenos exilados, podem ser interpretadas como um processo desencadeado pela reflexão e redefinição de suas funções e identidades sociais e políticas a partir do exílio. A atitude desses intelectuais teria sido conduzida na elaboração de tendências civis e políticas que se consubstanciariam em ativismo político. ${ }^{23}$ É nesse sentido que podemos interpretar a criação de Literatura Chilena en el Exilio, como iniciativa que buscou canalizar um modo específico de resistência cultural e política à ditadura através da veiculação da produção artístico-literária chilena e de sua respectiva crítica.

\section{Referências documentais e bibliográficas:}

AGGIO, Alberto. Democracia e Socialismo: a experiência chilena. São Paulo: Annablume, 2002.

ALEGRÍA, Fernando. Discurso Inaugural. Literatura Chilena en el Exilio, Los Angeles, n. 8, p. 22-24, 1978.

\footnotetext{
${ }^{23}$ Essa perspectiva mais positiva acerca do exílio e da tomada de posição pró-ativa por parte dos exilados, embora não seja a única, encontra-se em SZNAJDER; RONIGER (2013).
}

\section{GANPHLAC}

Revista Eletrônica da ANPHLAC, ISSN 1679-1061, №. 19, p. 152-185, jul./dez., 2015. http://revista.anphlac.org.br 
. La literatura chilena en el contexto latinoamericano. Araucaria de Chile, Madrid, n. 19, p. 113-119, 1982.

. Libros. Ilario Da. Relatos en el Frente Chileno (Barcelona: Editorial Blume, 1977). Literatura Chilena en el Exilio, Los Angeles, n. 7, p. 34, 1978.

. Literatura y revolución. México: Fondo de Cultura Económica, 1971.

13 , p. 17, 1980.

. Prisioneros Desaparecidos. Literatura Chilena en el Exilio, Los Angeles, n.

ALLENDE, Salvador. Últimas Palavras. Literatura Chilena en el Exilio, Los Angeles, $\mathrm{n}$. 4, p. 2, 1977.

ALTAMIRANO, Carlos. Introducción al volumen II. Élites culturales en el siglo XX latinoamericano. In: ALTAMIRANO, Carlos (org.). Historia de los intelectuales en América Latina II: los avatares de la "ciudad letrada" en el siglo XX. Buenos Aires: Katz Editores, 2010, p. 09-28.

ALZATE MEJÍA, Diana Maritza. Exilio y Dictadura, una percepción cinematográfica. 111f. Magíster en Historia. Universidad de Concepción. Departamento de Ciencias Históricas y Sociales, Faculdad de Humanidades y Arte, 2013.

ARAYA, Guillermo. El Hombre y la Tierra de América en el Canto General de Neruda. Literatura Chilena en el Exilio, Los Angeles, n. 9, p. 2-4, 1979.

Estructura del Canto General de Neruda. Literatura Chilena en el Exilio, Los Angeles, n. 7, p. 2-5, 1978.

Etapas en la obra de Pablo Neruda. Literatura Chilena en el Exilio, Los Angeles, n. 6, p. 2-4, 1978.

Lo Epico del Canto General de Pablo Neruda. Literatura Chilena en el Exilio, Los Angeles, n. 8, p. 2-4, 1978.

BEIGEL, Fernanda. Las revistas culturales como documentos de la historia latinoamericana. Utopia y Praxis Latinoamericana, Maracaibo, año 8, n. 20, p. 105-115, marzo, 2003.

BIANCHI, Soledad. Victor Jara, por los caminos del pueblo. Literatura Chilena en el Exilio, Los Angeles, n. 8, p. 5-7, 1978.

CARREÑO, Rubí. El exilio de la crítica chilena: aportes para una nueva agenda literária. Anales de Literatura Chilena, año 10, n. 12, p. 129-144, diciembre 2009.

\section{GANPHLAC}

Revista Eletrônica da ANPHLAC, ISSN 1679-1061, №. 19, p. 152-185, jul./dez., 2015. http://revista.anphlac.org.br 
CASALS ARAYA, Marcelo. El alba de una revolución: la izquierda y el processo de construcción estratégica de la "vía chilena al socialismo" (1956-1970). Santiago: Lom Ediciones, 2010.

CODDOU, Marcelo. Libros. José Leandro Urbina. Las Malas Juntas. Literatura Chilena en el Exilio, Ediciones de la Frontera, n. 9, p. 33, 1979.

Narrativa chilena en el exilio: notas de aproximación. Literatura Chilena en el Exilio, Los Angeles, n. 11, p. 8-11, 1979.

COELHO NETO, Raphael; PRATES, Thiago Henrique Oliveira. Revistas de intelectuais exilados como objeto de pesquisa: o caso de Araucaria de Chile e Encuentro de la Cultura Cubana. Faces da História, Assis-SP, v. 1, nº 1, p. 124-146, jan.-jun., 2014.

CONCHA, Jaime. La poesia chilena actual. Literatura Chilena en el Exilio, Los Angeles, n. 4, p. 9-13, 1977.

CORNELIUS, Hubert. Libros. Antonio Skármeta. Joven narrativa después del golpe (The American Hispanist, Indiana). Literatura Chilena en el Exilio, Los Angeles, n. 8, p. 34, 1978.

COSTA, Adriane Vidal. Intelectuais, política e literatura na América Latina: o debate sobre revolução e socialismo em Cortázar, García Márquez e Vargas Llosa. São Paulo: Alameda Editorial, 2013.

CYMERMAN, Claude. La literatura hispanoamericana y el exílio. Revista Iberoamericana, v. LIX, n. 164-165, p. 523-550, julio-diciembre de 1993.

DEVÉS-VALDÉS, Eduardo. Redes intelectuales en América Latina: hacia la constitución de una comunidad intelectual. Santiago: Universidad Santiago de Chile, 2007.

DÍAZ CASTILLO, Roberto. Testimonio de la lucha antifascista. Literatura Chilena en el Exilio, Los Angeles, n. 9, p. 5-6, 1979.

DONOSO FRITZ, Karen. Canción Huasa o Canto Nuevo? La identidad chilena en la visión de derechas e izquierdas. In: VALDIVIA, Verónica; VALLEJOS, Rolando Álvarez (orgs.). Su revolución contra nuestra revolución: la pugna marxista-gremialista en los ochenta. Santiago: LOM Ediciones, 2008, p. 231-261.

EDITORIAL. Literatura Chilena en el Exilio, Los Angeles, n. 1, p. 1, 1977.

EDITORIAL. Literatura Chilena en el Exilio, Los Angeles, n. 2, p. 1, 1977.

\section{GANPHLAC}

Revista Eletrônica da ANPHLAC, ISSN 1679-1061, N. 19, p. 152-185, jul./dez., 2015. http://revista.anphlac.org.br 
EPPLE, Juan Armando. Esa literatura que surge de un cerco de púas. Literatura Chilena en el Exilio, Los Angeles, n. 5, p. 7-8, 1978.

diciembre de 1981.

La literatura chilena del exilio. Texto Crítico, n. 22-23, p. 209-237, julioLibros. José Leandro Urbina. Las malas juntas. Literatura Chilena en el Exilio, Los Angeles, n. 14, p. 31, 1980.

FERNÁNDEZ RETAMAR, Roberto. Discurso de Clausura. Literatura Chilena en el Exilio, Los Angeles, n. 8, p. 27-28, 1978.

FUNES, Patricia. Salvar la nación: intelectuales, cultura y política en los años veinte latino-americanos. Buenos Aires: Prometeo Libros, 2006.

GILMAN, Claudia. Entre la pluma y el fusil: debate y dilemas del escritor revolucionário en América Latina. Buenos Aires: Siglo XXI, 2003.

LITERATURA CHILENA EN EL EXILIO. Libros. Matilde Ladron de Guevara. La Cienaga (Buenos Aires: Editorial Nueva, 1975). Literatura Chilena en el Exilio, Los Angeles, n. 5, p. 36, 1978.

Los héroes de septiembre tienen la palabra. Literatura Chilena en el Exilio, Los Angeles, n. 4, p. 1-8, 1977.

LITERATURA CHILENA, CREACIÓN Y CRÍTICA. David Valjalo. Literatura Chilena, Creación y Crítica, Santiago, n. 52 al 54, p. 137, 1990.

MARCO, Valeria de. A literatura de testemunho e a violência de Estado. Lua Nova, n. 62, p. 45-68, 2004.

MOREJÓN ARNAIZ, Idália. Política e polêmica na América Latina: Casa de las Américas e Mundo Nuevo. 326 f. Tese de Doutorado. Universidade de São Paulo (USP). Pró-Reitoria de Pesquisa, São Paulo, 2004.

MOULIAN, Tomás. Fracturas: de Pedro Aguirre Cerda a Salvador Allende (1938-1973). Santiago: LOM Ediciones, 2006.

NARVÁEZ, Jorge. Libros. José Leandro Urbina. Las Malas Juntas (Editorial Cordillera). Literatura Chilena en el Exilio, Los Angeles, n. 10, p. 35, 1979.

NÓMEZ, Naín. Transformaciones de la poesía chilena entre 1973 y 1988. Estudios Filológicos, Valdivia, n. 42, p. 141-154, sep. 2007.

\section{GANPHLAC}

Revista Eletrônica da ANPHLAC, ISSN 1679-1061, №. 19, p. 152-185, jul./dez., 2015. http://revista.anphlac.org.br 
NORAMBUENA, Carmem. El exilio chileno: río profundo de la cultura ibero-americana. Sociohistórica: Cuadernos del CISH, n. 23-24, p. 163-195, 2008.

PADRÓS, Enrique Serra. Repressão e violência: segurança nacional e terror de Estado nas ditaduras latino-americanas. In: FICO, Carlos; FERREIRA, Marieta de Moraes; ARAUJO, Maria Paula; QUADRAT, Samantha Viz (orgs.). Ditadura e Democracia na América Latina: balanço histórico e perspectivas. Rio de Janeiro: FGV, 2008, p. 143-178.

PATIÑO, Roxana. América Latina: literatura e crítica em revista(s). In: SOUZA, Eneida M. de; MARQUES, Reinaldo (orgs.). Modernidades alternativas na América Latina. Belo Horizonte: Editora UFMG, 2009, p. 456-470.

RAMA, Ángel. La riesgosa navegación del escritor exilado. Nueva Sociedad, Buenos Aires, n. 35, p. 95-105, março-abril, 1978.

ROJAS MIRA, Claudia Fedora. El Exilio Político Chileno: la Casa de Chile en México (1973-1993), una experiencia singular. Tesis. 225 f. Universidad de Santiago de Chile. Instituto de Estudios Avanzados - Faculdad de Humanidades, 2013.

SELIGMANN-SILVA, Márcio (org.). História, Memória e Literatura: o testemunho na era das catástrofes. Campinas: Editora da Unicamp, 2003.

SILVA, Êça Pereira da. Araucaria de Chile: a intelectualidade chilena no exílio (19781989). 166f. Dissertação (Mestrado). Universidade de São Paulo, Faculdade de Filosofia, Letras e Ciências Humanas, 2009.

STREJILEVICH, Nora. El arte de no olvidar: literatura testimonial en Chile, Argentina y Uruguay entre los 80 y los 90. Buenos Aires: Catálogos, 2006.

SUBERCASEAUX, Bernardo. Historia de las ideas y de la cultura en Chile: desde Independencia hasta el Bicentenario. Santiago de Chile: Editorial Universitaria, v. III, 2011.

SZNAJDER, Mario; RONIGER, Luis. La política del destierro y el exilio en América Latina. México: Fondo de Cultura Económica, 2013.

TAPIA VALDÉS, Jorge. El terrorismo de Estado: la Doctrina de la Seguridad Nacional en el Cono Sur. Ciudad de Mexico, Nueva Sociedad: Editorial Nueva Imagen, 1980.

VALJALO, David. Carta del editor. In: Indice general: Literatura Chilena, Creación y Crítica (1981, 1982, 1983). Los Angeles: Ediciones de la Frontera, 1984.

VIDAL, Paloma. A história em seus restos: literatura e exílio no Cone Sul. São Paulo: Annablume, 2004.

\section{GANPHLAC}

Revista Eletrônica da ANPHLAC, ISSN 1679-1061, №. 19, p. 152-185, jul./dez., 2015. http://revista.anphlac.org.br 
WYMAN, Eva Goldschmidt. Los poetas y el general: voces de oposición en Chile bajo Augusto Pinochet (1973-1989). Santiago: LOM Ediciones, 2002.

\section{Páginas da Internet:}

Fernando Alegría (1918-2005), una fundación imaginaria de Chile. Disponível em: http://www.memoriachilena.cl/602/w3-article-3422.html. Acesso em: 25/06/2013.

\section{GANPHLAC}

Revista Eletrônica da ANPHLAC, ISSN 1679-1061, №. 19, p. 152-185, jul./dez., 2015. http://revista.anphlac.org.br 